\title{
Characterisation of food security and consumption patterns among smallholder livestock farmers in Botswana
}

\author{
Sirak Bahta ${ }^{*}$, Francis Wanyoike ${ }^{2}$, Hikuepi Katjiuongua ${ }^{3}$ and Davis Marumo ${ }^{4}$
}

\begin{abstract}
Background: Achievement of food security is an important objective in the National Development Plan of Botswana. This study set out to characterise food security situation and food consumption patterns among livestock keepers in Botswana. The study also sought to determine the effect of various factors (including livestock-related issues) on nutrition/food consumption patterns of livestock farmers in Botswana. Data used in this study come from a survey of smallholder livestock producers conducted by the International Livestock Research Institute and its partners in Botswana in 2013. A food consumption score (FCS) is a qualitative measure of food security constructed using data collected at a household level, and to investigate the influence of various factors on food security and consumption patterns, both logit and OLS regression were used.

Results: Results show that purchase was the chief source of foodstuffs (including main staples) in these households. About $20 \%$ of households claimed that they had suffered lack of food at least once during the preceding 12 months prior to the collection of data used in this analysis. Nearly all of them reported having had to endure going to bed hungry. Application of the World Food Programme (WFP) FCS methodology of food security analysis supported this claim. Based on the FCS, about $9 \%$ of households were food insecure. This category constituted $6 \%$ that ranked poorly and $3 \%$ that were on the borderline according to the WFP's definition of food security. These findings justify continued efforts to ensure realisation of food security among livestock keepers in Botswana.

Conclusion: The results from this study justify continued, but well-targeted efforts to ensure realisation of food security among livestock keepers in Botswana. The significant effect that livestock keeping has on food security implies that promotion of the livestock activities, especially in the rural areas, could foster alleviation of malnutrition, especially among the poor.
\end{abstract}

Keywords: Food security, Nutrition, Livestock keepers, Botswana

\section{Background}

Although Botswana has one of the highest per capita levels of income in Africa, food security at both the household and national levels remains a challenge-a situation mainly precipitated by the structure of the economy and arid climates. Over $70 \%$ of Botswana's population resides in the rural areas [1], and majority (70\%) relies on traditional/subsistence agriculture for their livelihoods [1]. Commercial farming is not a prominent economic

\footnotetext{
*Correspondence: s.bahta@cgiar.org

1 International Livestock Research Institute (ILRI), Gaborone, Botswana Full list of author information is available at the end of the article
}

activity in Botswana [1, 2]. Overall, the agricultural sector accounts for only $1.9 \%$ of the national income compared to the industry, and service sectors account for 28.7 and $69.4 \%$, respectively $[1,3]$. The country is characterised by high inequality with about $20 \%$ of the population living below the poverty datum line (PDL), while $30 \%$ is either unemployed or underemployed [4].

The diminished share of agricultural production in Botswana's national economy is mainly attributable to the rapid growth of other sectors notably mining (especially diamonds), tourism and manufacturing [5]. However, available data also show that productivity in the 
agricultural sector has stagnated over many years with levels in the widespread traditional/subsistence sub-sector often being many times lower than in the relatively tiny commercial sub-sector. For example, in 2013, maize yields in the traditional sub-sector averaged only $22 \mathrm{~kg}$ per hectare planted compared to $675 \mathrm{~kg}$ in the commercial sub-sector and the trend was the same for millet, beans and sorghum. By the same token, commercial livestock producers outperformed their counterparts in the subsistence/traditional sub-sector in terms of high offtake and low mortality rates of animals [2].

The main factors accounting for the poor performance of the Botswana's agriculture sector are numerous. First, Botswana's climate is largely arid to semi-arid and crop farming is confined to only a small area of about 2500$3800 \mathrm{sq} \mathrm{km}$ on the eastern and northern margins of the country [6]. Second, crop production is mainly rain fed and yields tend to be poor due to low and erratic rainfall [1]. Third, the rate of adoption of modern farming methods and practices by farmers in the traditional/subsistence sector is low leading to low yields $[5,2]$. Other factors include poor soils and also animal and plant diseases and pests [5]. Amidst this poor performance of the agricultural sector, the national policy on agricultural development shifted from food self-sufficiency to food security in 1991 with the focus being on access to food at affordable prices irrespective of source, that is, domestic or imported [7]. This policy shift saw the removal of trade-restricting border measures in the grain industry, leading to increases in food imports. Currently, the country imports about $90 \%$ of the national food supply [6].

Despite the policy change, challenges still remain in ensuring that all persons and households have access to food at all times. For example, during an analysis of the impacts of rising international food prices for Botswana, BIDPA [7] reported that food prices tended to be highest in the rural areas already disadvantaged by relatively low levels of income and high rates of unemployment. Similarly, according to FAO [8], over $30 \%$ of the people in the country suffered chronic undernourishment. Consistent with the United Nations (UN) former development goal, the millennium development goal (MDG), on hunger and poverty eradication, realisation of food security is an important objective in Botswana's National Development Plan (NDP 10). Similarly, consistent with the UN sustainable development goals (SDGs), the recently ratified National Development Plan (NDP 11) targets to reduce the number of people living under the poverty line by $50 \%$ by the year 2020 and increase daily dietary energy supply (DES) from 2150 to $2600 \mathrm{kcal}$ per person by 2010 , and further to 2700 by 2016 and thereafter. Besides, efforts aimed at increasing household food production spelt out in the NDP and the government has initiated numerous programmes to combat malnutrition [9].

Largely due to climatic reasons and tradition, the agricultural sector in Botswana is dominated by livestock farming with smallholder livestock producers accounting for about $70 \%$ of the agricultural GDP [10]. Not much is, however, known about these smallholder livestock farmers food security situation. Past studies of Botswana's food security studies have shallowly investigated food security. For example, Acquah et al. [6] investigated food security in Gaborone using a fair sample size and different types of food security scores. Similarly, Moreki et al. [11] and Legwaila et al. [12] have, respectively, investigated the role of village chicken and traditional plants in food security. Limitations of these studies include that they either failed to empirically determine the effects of various factors on food security, and/or the studies are focused on a very narrow segment of the population.

The current study, set out to characterise the food security patterns and food security situation among the subsistence livestock keepers, employed a rigorous empirical method to address these shortcomings using farm-level cross-sectional survey data collected under the auspices of a development research project. ${ }^{1}$ The survey was implemented in three districts (Southeast, Chobe and Central) of Botswana. The study was motivated by the current lack of knowledge on whether the efforts employed to combat food insecurity were bearing fruits. The study also sought to determine the empirical effects of various factors (including livestock-related issues) on nutrition/food consumption patterns.

The remaining part of the paper is organised as follows: section two presents the methodological approach used in the study and the description of the characteristics of the surveyed households. Section three provides the results of the econometric analysis followed by section four which provides a detailed discussion of the findings. Finally, section five presents some conclusions and policy implications of the findings.

\section{Methodological approach}

Data used in this study come from a survey of smallholder livestock producers conducted by the International Livestock Research Institute (ILRI) and its partners in Botswana in 2013. During the survey, a random sample of 600 livestock keepers were interviewed using a structured questionnaire which included a module on

\footnotetext{
${ }^{1}$ The Smallholder Livestock Competitiveness Project is funded by the Australian Centre for International Agricultural Research (ACIAR) and implemented by the International Livestock Research Institute (ILRI) in partnership with the Botswana Ministry of Agriculture's Department of Agricultural Research (DAR).
} 
frequency of consumption of various food stuffs during the past 2 weeks. Using this survey data and an adaptation $^{2}$ of a methodology for measuring food security among communities by the World Food Program (WFP) $[13,14]$, the study computed a food consumption score (FCS) for each household which was then used to generate a hierarchical ranking of the households in terms of their food security status.

A FCS is a qualitative measure of food security constructed using data collected at a household level. Unlike quantitative $^{3}$ measures of food security which are more tedious and costly to assemble [13], qualitative measures are often used by organisations because the information required to construct them is less time-consuming and costly to collect $[14,15]$. The procedure on construction and use of FCS in food security analysis is outlined in WFP VAM [14].

First, the various foodstuffs consumed in a community are categorised into eight standard food groups: main staples, pulses, vegetables, fruits, meat and fish, milk, sugar, and oil. Second, for each household, using data on frequency of consumption of the various food stuffs, a food group consumption frequency score (FGCFS) is computed by summing up the number of days the various foodstuffs in the food group have been consumed. In this study, the FGCFS was allowed to have a maximum value of 14 consistent with the 14-day data used in contrast to the 7-day data recommended by WFP VAM (op cit.) who consequently propose a truncating FGCFS value of 7 . Therefore, in this study, cases where the computed FGCFS fell above 14 were changed to 14 .

Next, the FGCFS was multiplied by assigned weights ${ }^{4}$ [14] based on respective food group's nutrient content to generate weighted food group scores (WFGS). The WFGS were then summed across the food groups obtaining the FCS. On the basis of the FCS, hierarchical categories of households by their food security status were generated, namely households with poor, borderline and adequate food consumption score. In the current study, a FCS of 42 or less was considered poor, while 70.5 or above was considered adequate. Borderline FCS included those scores between 42.5 and 70 . These cut-off points

\footnotetext{
${ }^{2}$ Instead of the 7 days food frequency consumption data commonly used in the WFP methodology, we used 14 days data.

${ }^{3}$ Quantitative measures of food security use data collected primarily at individual level to calculate dietary energy and nutrient intakes, which are then compared with nutrient requirements.

${ }^{4}$ The multiplying weights used in the generation of the weighted food group scores are based on interpretation by scientists about the caloric density, macro- and micronutrient content, and also actual quantities of the different food groups typically eaten. The highest weights are attached to foods with relatively high energy, good quality protein, and a wide range of micronutrients that can be easily absorbed.
}

were double than those recommended by WFP VAM (op cit.) because of the 2-week food consumption frequency data utilised in this study.

To investigate the influence of various factors on food security and consumption patterns, both logit and OLS regression were used. The logit model is commonly used in empirical analysis of phenomena where the dependent variable always takes a value of either 1 or zero (0) $[16,17]$. In the current study, the logit model was used to investigate the influence of various factors on the probability of a household falling among those categorised as food insecure. The logit model was specified as follows:

$$
P_{i}=F\left(x_{i}^{\prime} \beta\right)=1 /\left[1+\exp \left(-x_{i}^{\prime} \beta\right)\right]
$$

where $\mathrm{Pi}$ is the probability of a household being in the category of those with poor FCS, $\beta$ is a vector of unknown parameters and $\mathrm{Xi}$ is a $\mathrm{K} \times \mathrm{N}$ matrix of farm and farmer characteristics hypothesised to exert influence on food security in households. These explanatory variables (see Table 1 ) included age, gender (male $=1$ and 0 otherwise), years of formal education, main occupation (crop farming, livestock keeping, formal employment, business and retired) of the household head; size of household including number of adults and children; geographical location, that is, district where the farm is located (Chobe, Central or South East); access to grazing and cropping land; numbers of livestock (cattle and small ruminants) kept; and claim by respondents that the household had experienced lack of food in the preceding 12 months before they were interviewed for data used in this study.

A potential drawback in solely using a logit model to analyse the determinants of household food security is that it disregards variability in FCS across households with similar hierarchical ranking in terms of food security. Thus, an OLS model was also estimated to determine the effects of various factors on the estimated household food security status, represented by the FCS. The OLS model was specified as follows:

$$
Y_{i}=\beta X_{i}+e_{i}
$$

where $Y_{\mathrm{i}}$ is the computed FCS in the ith household, $\mathrm{X}_{\mathrm{i}}$ is a $\mathrm{K} \times \mathrm{N}$ matrix of explanatory variables as used in the logit model (see Table 1), $\beta$ is a vector of unknown parameters to be estimated and $e_{i}$ is a $1 \times \mathrm{N}$ vector of unobservable random error term assumed to be normally distributed with mean $=0$ and variance $=\sigma^{2}$.

Table 1 also shows the expected effect of the various explanatory variables on food security. A positive sign implies that the variable enhances food security and vice versa for a negative sign. The choice of explanatory variables was informed by economic theory, objectives, and the literature on food security and nutrition. Ownership 
Table 1 Summary of the explanatory variables used in the estimated logit model

\begin{tabular}{|c|c|c|c|}
\hline Explanatory variable & Code & Type of variable & Expected sign \\
\hline$X_{1}=$ Age of the household head & Number of years & Continuous & - \\
\hline$x_{2}=$ Gender of the household head & 1 if male, 0 if female & Dummy & $+/-$ \\
\hline$x_{3}=$ Years of formal education & Number of years & Continuous & + \\
\hline$X_{4}=$ Main occupation of the household head & $\begin{array}{l}1=\text { Crop farming; } \\
2=\text { Livestock keeping; } \\
3=\text { Formal employment } \\
4=\text { Non-farm business } \\
5=\text { Retired }\end{array}$ & Dummy & $+/-$ \\
\hline$x_{5}=$ Size of household & Number of people & Continuous & + \\
\hline $\begin{array}{l}x_{6}=\text { Geographical location of farm (basis of compari- } \\
\text { son = South East) }\end{array}$ & $\begin{array}{l}1=\text { Chobe district; } 2=\text { Central district; } 3=\text { South east } \\
\text { district }\end{array}$ & Dummy & $+/-$ \\
\hline$x_{7}=$ Access to grazing & 1 if yes, 0 otherwise & Dummy & + \\
\hline$X_{8}=$ Access to cropping land & Number of hectares & Continuous & + \\
\hline$X_{9}=$ Livestock units kept & No. of livestock units & Continuous & + \\
\hline $\begin{array}{l}x_{10}=\text { Household had suffered food unavailability during } \\
\text { the last year }\end{array}$ & 1 if yes, 0 otherwise & Dummy & $+/-$ \\
\hline
\end{tabular}

of resources (including land and different types of livestock) was expected to have a positive effect on food security due to their effect on food production and household income. This is consistent with findings by [18] in Mozambique. Likewise, in line with results from a cross-country study by [19] which demonstrated strong negative relationship between lack of education and food insecurity, years of schooling of household head was hypothesised to have a positive effect on food security.

Gender of household head was included in the regression model as a dummy variable with a value of 1 if the head of the household was male and 0 otherwise. Although the available literature showed no universal relationship between gender of household head versus poverty and vulnerability [20], gender classification of households in this analysis differs with common practice in many past studies. In this study, families where husbands lived away were categorised as "male"- instead of "female"-headed as in many past studies. This leaves households of single women (unmarried with children, divorced and/or widowed) which tend to be relatively poorer [20] and therefore more likely to be food insecure as our basis of comparison. For this reason, gender of household head was expected to have a positive effect on food security.

The econometric modelling also features household size in terms of numbers of "adult persons" and "children" as explanatory variables consistent with the findings by Garret and Ruel (op cit) which demonstrated that family size and composition may affect food security status of the household.

A higher number of adult family members may be associated with availability of more labour resource which can be sold or used for own food production. Therefore, farm size was expected to impact positively on food security. Conversely, household with high numbers of children may be forced to devote fewer resources to purchasing food in order to attend to other needs of children including health, clothing and education. A negative relationship was therefore expected between high numbers of children versus household food security.

The inclusion of dummy variables for each geographical location of farm households as explanatory variables represents an attempt to account for the communitylevel variables that may influence food security in these households. Such community-level variables may relate to physical environment and economic characteristics of the study sites (Garret and Ruel, op cit). Dummy variables were included for Chobe and Central Districts, while South East District was used as a basis for comparison. Chobe and Central Districts are relatively more rural than South East District which is the smallest district in Botswana and is located adjacent to the capital city, Gaborone [21]. Chobe District, situated in the northern part of Botswana, receives the highest and least variable amount of rainfall, 550-650 $\mathrm{mm}$ [22].

\section{Characteristics of the surveyed households}

Table 2 presents a summary of descriptive statistics on the surveyed households. Fifty-nine observations were dropped from the analysis due to the problem of missing values for some variables. Results are only shown for the 541 observations utilised in the quantitative analysis of factors influencing food security. The three surveyed districts were well represented in the 541 observations with 
Table 2 Selected farm and farmer characteristics in the surveyed households $(N=541)$

\begin{tabular}{|c|c|c|c|c|}
\hline & Mean & SD & Min & Max \\
\hline Gender of household head( $1=$ male, $0=$ otherwise $)$ & 0.79 & 0.41 & 0 & 1.00 \\
\hline Age (yrs) of household head & 60.44 & 13.44 & 26.00 & 96.00 \\
\hline Years of schooling of household head & 4.90 & 4.77 & 0 & 18.00 \\
\hline Number of adults in the household & 3.52 & 2.14 & 1.00 & 21.00 \\
\hline Number of children in the household & 1.11 & 1.45 & 0 & 9.00 \\
\hline Size of crop land $(\mathrm{Ha})$ & 6.27 & 14.27 & 0 & 270.00 \\
\hline Number of heads of cattle kept & 34.60 & 55.26 & 0 & 474.00 \\
\hline Number of shoats kept & 4.84 & 20.55 & 0 & 250.00 \\
\hline Claim that a household had experienced food unavailability during the past 12 months ( $1=$ yes, $0=$ otherwise) & 0.20 & 0.40 & 0 & 1.00 \\
\hline \multicolumn{5}{|l|}{ District } \\
\hline Central district & 0.35 & 0.48 & 0.00 & 1.00 \\
\hline Chobe district & 0.28 & 0.45 & 0.00 & 1.00 \\
\hline South east & 0.37 & 0.48 & 0.00 & 1.00 \\
\hline \multicolumn{5}{|l|}{ Main activity of the household head } \\
\hline Crop farming & 0.53 & 0.50 & 0.00 & 1.00 \\
\hline Livestock keeping & 0.79 & 0.40 & 0.00 & 1.00 \\
\hline Formal employment & 0.26 & 0.44 & 0.00 & 1.00 \\
\hline Business & 0.09 & 0.28 & 0.00 & 1.00 \\
\hline Retired & 0.29 & 0.45 & 0.00 & 1.00 \\
\hline Access to grazing land & 0.91 & 0.28 & 0.00 & 1.00 \\
\hline Access to cropping land & 0.75 & 0.43 & 0.00 & 1.00 \\
\hline
\end{tabular}

$37 \%$ of the observations being in South East, $35 \%$ in Central and 28\% in Chobe Districts.

About $80 \%$ of the households were male-headed, implying that female-headed households accounted for about $20 \%$ of the sample. The implied percentage of female-headed households in this study is low compared to $47-67 \%$ reported in studies by Moepeng and Tisdell [23] and Central Statistics Office Botswana [24]. Recall that in the current study households where men lived away were categorised as male rather than female-headed since it is very likely that the power of decision-making continues to reside with the male, a demographic head [25].

Heads of households were elderly (average age $=60.4$ years) with rather low levels of formal education (mean $=4.9$ years of schooling). Consistent with data from Statistics Botswana [26], households tended to be small with a mean of 4.6 persons each and these included 3.5 adults and 1.1 children. Majority of heads of households had livestock keeping and crop farming as their main economic activities (79 and 52\%, respectively). Other commonly cited occupations included formal employment and business (26 and 9\%, respectively).

Majority of the respondents indicated that they had access to grazing and cropping land (91 and 75\%, respectively). Cattle were the predominant species of livestock kept. On average, a household kept about 35 heads of cattle compared to only 4.8 small ruminants (sheep and goats). This discrepancy in numbers of cattle versus small ruminants kept is rather large when compared with data from Statistics Botswana [26] which shows that the country has a total of about 2.1 million heads of cattle and 1.8 million sheep and goats. This discrepancy owes to the fact that the study purposively targeted smallholder households where a cattle rearing was the dominant activity. Most of the small stock animals are reared on the Western and South Western part of Botswana, which are not part of the survey. In addition, as it is shown in Table 2, the large values of standard deviation associated with numbers ofcattle and small ruminants owned per household show that there is wide variation in livestock ownership in the study area.

A few variables exhibited significant variation across districts. On average, households in the South East District had significantly fewer children (0.78) than in Central and Chobe districts (1.23 and 1.41, respectively). Likewise, size of cropping land and number of herds of cattle kept tended to be lower in the South East District (means $=2.85$ ha and 18.43 heads) compared to the other two districts (mean (Central) $=6.52$ ha and 31.64 heads; mean (Chobe) 9.76 ha and 54.49 heads). This could be due to the high population density per square kilometre in South East district, a small district closer to the capital city, Gaborone [27]. Rearing of sheep and goats 
was comparatively more common among households in Chobe (mean $=11.49$ animals per household) than the South eastern and Central district (0.52 and 1.93 animals per household, respectively).

\section{Results}

\section{Food consumption patterns}

Table 3 shows the consumption patterns of various foodstuffs among the surveyed livestock producers. Despite widespread reliance on agriculture as a source of livelihood, purchase was the chief source of foodstuffs (including main staples) among the surveyed livestock keepers. Households that cited own production as a source of food represented less than $30 \%$ of the surveyed households for all the food commodities. This result confirms findings by BIDPA [7] which showed that households in Botswana spent the highest proportion of their income $(24 \%)$ on food. The most widely and regularly consumed main staples included maize, sorghum and wheat $(79-80 \%$ of households at an average frequency of 7.8-9.8 days in a fortnight). Vegetables were also widely (78\% of households) and regularly consumed (on average 8.1 days in a fortnight).

Table 3 Food consumption patterns among livestock producers in Botswana

\begin{tabular}{|c|c|c|c|c|c|c|c|c|c|}
\hline & \multirow{2}{*}{$\begin{array}{l}\% \text { of house- } \\
\text { holds } \\
(N=541)\end{array}$} & \multirow{2}{*}{$\begin{array}{l}\text { Number } \\
\text { of days con- } \\
\text { sumed }\end{array}$} & \multicolumn{7}{|c|}{$\%$ of respondents citing their source of various food commodities consumed $(N=541)$} \\
\hline & & & $\begin{array}{l}\text { Own produc- } \\
\text { tion }\end{array}$ & $\begin{array}{l}\text { Hunting/ } \\
\text { gathering/ } \\
\text { fishing }\end{array}$ & $\begin{array}{l}\text { Cash Pur- } \\
\text { chase }\end{array}$ & $\begin{array}{l}\text { Gifts } \\
\text { (friends/ } \\
\text { relatives) }\end{array}$ & $\begin{array}{l}\text { Bought } \\
\text { on credit }\end{array}$ & $\begin{array}{l}\text { Food assis- } \\
\text { tance }\end{array}$ & Others \\
\hline Millet & 7 & 4.6 & 22 & & 71 & 7 & & & \\
\hline Sorghum & 86 & 9.8 & 8 & 0.2 & 90 & 1 & 0.2 & 0.4 & \\
\hline $\begin{array}{l}\text { Maize (include } \\
\text { pap) }\end{array}$ & 87 & 9.2 & 2 & & 97 & & & 0.8 & \\
\hline $\begin{array}{l}\text { Wheat flour } \\
\text { (include } \\
\text { bread) }\end{array}$ & 79 & 7.8 & & 0.4 & 98 & 0.2 & 0.2 & 0.9 & \\
\hline Local grains & 4 & 7.4 & & & 95 & & & & \\
\hline Rice & 66 & 4.1 & & & 97 & 1 & & 1 & 1 \\
\hline Fruits & 51 & 6.1 & 5 & 5 & 89 & 1 & & & \\
\hline Vegetables & 78 & 8.1 & 13 & 1 & 85 & 1 & & 0.2 & 0.2 \\
\hline $\begin{array}{l}\text { Beans, peas, } \\
\text { lentils, or } \\
\text { nuts }\end{array}$ & 57 & 3.8 & 18 & 0.3 & 70 & 5 & & 5 & 2.3 \\
\hline Eggs & 28 & 4.6 & 18 & & 81 & 1 & & & 1 \\
\hline $\begin{array}{l}\text { Poultry: } \\
\text { chicken, } \\
\text { duck, other } \\
\text { poultry }\end{array}$ & 13 & 6.1 & 3 & & 96 & 1 & & & \\
\hline Beef & 13 & 6.0 & 6 & & 94 & & & & \\
\hline Pork & 23 & 3.6 & 28 & & 62 & 9 & & & 1 \\
\hline Lamb, mutton & 33 & 6.8 & 4 & 17 & 77 & 1 & & & \\
\hline Goat meat & 62 & 10.5 & 22 & 0.3 & 76 & 0.3 & & 0.3 & \\
\hline $\begin{array}{l}\text { Fresh or dried } \\
\text { fish or } \\
\text { shellfish }\end{array}$ & 79 & 12.1 & 2 & 1 & 97 & & & 0.4 & \\
\hline $\begin{array}{l}\text { Milk, cheese, } \\
\text { yogurt, or } \\
\text { other milk } \\
\text { product }\end{array}$ & 84 & 12.8 & 1 & 0.2 & 98 & 0.4 & 0.2 & & \\
\hline Oils and fats & 66 & 6.2 & 18 & 1 & 80 & 1 & & & \\
\hline $\begin{array}{l}\text { Sweets, sugar, } \\
\text { honey }\end{array}$ & 72 & 7.9 & 7 & 0.2 & 88 & 3 & & 0.7 & 1 \\
\hline $\begin{array}{l}\text { Other condi- } \\
\text { ments: } \\
\text { coffee, tea, } \\
\text { milk in tea }\end{array}$ & 88 & 12.8 & 0.2 & 0.2 & 99 & 0.2 & 0.2 & 0.2 & \\
\hline
\end{tabular}


Fish was the leading source of animal proteins and accounted for $79 \%$ of the surveyed households. Majority of them (about $80 \%$ ) consumed fish on a daily basis. Goat meat was the second best source of animal proteins and represented about $62 \%$ of the surveyed goat meat was consumed during the 2-week period preceding the study compared to eggs, poultry meat, beef, pork, lamb and mutton (which accounted for $13-33 \%$ of the households). Consumption of milk and other dairy products was widespread among the selected districts. A larger proportion $(84 \%)$ of the households consumed milk and dairy products on a daily basis in the fortnight considered. Surprisingly, in a country where rearing of cattle was widespread, purchase still remained the most frequently cited source of milk and dairy products consumed ( $98 \%$ of surveyed households) as opposed to own production (< $1 \%$ of milk/dairy product consumers). This could be attributed to the wide availability of small stores which sale pasteurised milk and the awareness of communities on quality and safety issues that emanated from the continuous efforts of the Ministry of Health in informing societies about food-borne diseases associated with raw milk consumption. Added factor could also be the non-dairy nature of the cattle breeds owned by these households. The arid to semi-arid climate of Botswana is mostly suited for beef cattle breeds which produce minimal milk.

\section{Food security status}

Besides the use of food consumption frequency data to assess the food security situation among livestock producers in Botswana, livestock keepers were also explicitly probed about food availability in their households during the past 12 months prior to the household survey. Results suggested food insecurity in some households with about $20 \%$ of the respondents, claiming that they had suffered lack of food at least once during the past year and nearly all of them having had to endure going to bed hungry (Table 2).

Results of the food consumption frequency analysis confirmed a presence of food insecurity in some of the households. On the basis of the FCS, about $9 \%$ of households were found to be food insecure. This category of households included $6 \%$ of households that ranked poorly and $3 \%$ that were on the borderline according to the WFP's definition of food security. The estimated number of food insecure households in the South East District was relatively low (5\%) compared to Chobe and Central districts (10 and 13\%, respectively). This geographical distribution of the food insecure households probably reflects the effect of urbanisation on food availability. The households in the South East District, which is more urbanised, were relatively less poor and thus less food insecure than those in Chobe and Central districts.

The overall estimate of the number of food insecure households based on the FCS methodology was low (9\%) compared to the number of households who claimed to have suffered hunger during the previous 1 year (20\%). This wide discrepancy may be attributable to a couple of reasons. First, the food availability situation in some of the affected households may have changed between the time when they suffered hunger and the period when data used for this study were collected. Additionally, past studies such as [13] have demonstrated a tendency for the FCS methodology to underestimate the prevalence of food insecurity. Nevertheless, the method is still considered to be generally reliable and is widely used [13-15].

Table 4 presents the results of the effects of various factors on food security situation in the surveyed households at the time of collection of data used in this study. For the logit model, the dependent variable equals one for households with poor FCS and zero otherwise. The logit coefficients therefore show the effect of the factors included as explanatory variables in the model on the log of the odds of a household being food insecure. Results of the $X^{2}$ test indicated that the model was statistically significant in explaining the variability in the data $(P=1 \%)$.

Livestock producers in the Chobe and Central Districts were significantly more likely to have poor FCS $(P=1$ and $5 \%$, respectively) compared to their counterparts in the SE District. As already noted, this higher likelihood of higher prevalence of food insecurity in the two rural districts is perhaps due to the higher incidence of poverty in the rural areas of these districts where most of the households interviewed reside [1].

As expected, higher number of adults persons in a household lowered the probability of that household being food insecure $(P=5 \%)$. However, contrary to apriori expectations, households with higher number of children were found to be less likely to be food insecure $(P=1 \%)$. This effect of number of children food security in households probably shows the contribution of children in productive activities in their farm households. Alternatively, the result perhaps reflects the impact of nutrition programmes targeting children or households with children which has been identified as one of the reasons why the FCS methodology understates the prevalence of food insecurity [13].

Households that reported that they had experienced lack of food during the past 12 months prior to the household survey were significantly more likely to be food insecure $(P=10 \%)$ rendering credence to their claim. Conversely, being a livestock keeper and having access to grazing land mitigated the probability of a household 
Table 4 Determinants of food security status in the surveyed households

\begin{tabular}{|c|c|c|c|c|c|c|}
\hline & \multicolumn{3}{|c|}{ Logit $(Y=$ Poor $)$} & \multicolumn{3}{|c|}{ OLS $(Y=\mathrm{FCS})$} \\
\hline & Coeff. & SE & $P>z$ & Coeff. & SE & $P>t$ \\
\hline Constant & -0.94 & 1.98 & 0.64 & $87.96^{* * *}$ & 14.45 & 0.00 \\
\hline Gender of household head ( $1=$ male, $0=$ otherwise) & -0.01 & 0.54 & 0.99 & -1.38 & 4.04 & 0.73 \\
\hline Age (yrs) of household head & 0.01 & 0.02 & 0.60 & -0.08 & 0.17 & 0.66 \\
\hline Years of schooling of household head & 0.03 & 0.06 & 0.61 & 0.63 & 0.42 & 0.14 \\
\hline Number of adults in the household & $-0.31^{* *}$ & 0.15 & 0.04 & $1.96^{* * *}$ & 0.78 & 0.01 \\
\hline Number of children in the household & $-0.99^{* * *}$ & 0.29 & 0.001 & $4.26^{* * *}$ & 1.16 & 0.00 \\
\hline Size of crop land $(\mathrm{Ha})$ & 0.002 & 0.02 & 0.92 & -0.02 & 0.12 & 0.84 \\
\hline Number of heads of cattle kept & -0.001 & 0.01 & 0.82 & 0.00 & 0.04 & 0.93 \\
\hline Number of shoats kept & 0.01 & 0.01 & 0.61 & 0.11 & 0.09 & 0.23 \\
\hline $\begin{array}{l}\text { Claim that a household had suffered food unavailability during the last year }(1=\text { yes, } 0=\text { other- } \\
\text { wise) }\end{array}$ & $0.95^{*}$ & 0.49 & 0.06 & $-9.49^{* *}$ & 4.20 & 0.02 \\
\hline \multicolumn{7}{|l|}{ District (control $=$ SE) } \\
\hline Central & $1.82^{* *}$ & 0.76 & 0.02 & $-10.40^{* * *}$ & 4.22 & 0.01 \\
\hline Chobe & $1.98^{* * *}$ & 0.72 & 0.01 & $-13.26^{* * *}$ & 4.36 & 0.00 \\
\hline \multicolumn{7}{|l|}{ Main activity of the household head } \\
\hline Crop farming & 0.17 & 0.57 & 0.76 & 2.69 & 3.88 & 0.49 \\
\hline Livestock keeping & $-2.75^{* * *}$ & 0.63 & 0.00 & $15.54^{* * *}$ & 4.51 & 0.00 \\
\hline Formal employment & -0.58 & 0.63 & 0.36 & $7.54^{*}$ & 4.39 & 0.09 \\
\hline Business & -0.83 & 1.12 & 0.46 & 8.35 & 6.17 & 0.18 \\
\hline Retired & -0.63 & 0.65 & 0.33 & 6.55 & 4.59 & 0.15 \\
\hline Access to grazing gland $(0,1)$ & $-2.26^{* *}$ & 0.99 & 0.02 & $38.17^{* * *}$ & 7.37 & 0.00 \\
\hline Access to cropping land $(0,1)$ & 1.21 & 0.84 & 0.15 & -6.70 & 4.77 & 0.16 \\
\hline$N=541$ & \multicolumn{6}{|l|}{$N=541$} \\
\hline $\operatorname{LR} x^{2}(10)=83.4$ & \multicolumn{6}{|c|}{$F(18,522)=6.06$} \\
\hline Prob $>x^{2}=0.00$ & \multicolumn{6}{|c|}{ Prob $>F=0.00$} \\
\hline Pseudo $R^{2}=0.36$ & \multicolumn{6}{|c|}{$R$-squared $=0.17$} \\
\hline \multirow[t]{2}{*}{ Log likelihood $=-74.2$} & \multicolumn{6}{|c|}{ Adj R-squared $=0.14$} \\
\hline & \multicolumn{6}{|c|}{ Root MSE $=37.26$} \\
\hline
\end{tabular}

Statistical significance levels: ${ }^{* *} 1 \% ;{ }^{* *} 5 \%$; ${ }^{*} 10 \%$

being food insecure ( $P=1$ and 5\%, respectively). This reinforces the importance of the livestock rearing activities and the access to grazing land on the livelihoods of the people of Botswana.

The results of the OLS regression of FCS on the various factors hypothesised to influence food security are also presented in Table 4. The OLS model was statistically significant in explaining the variability in the data $(P=1 \%)$ although the value of the adjusted $R^{2}$ was rather low. The OLS coefficients show the effect of the dependent variables on the values of the food consumption score (FCS). Quite clearly, OLS regression results were highly consistent with the results of the logit regression. Households in the Central and Chobe Districts had significantly higher values of FCS ( $P=1 \%$ in both cases). Higher numbers of adult persons and also children had a positive effect on the FCS ( $P=1 \%$ for both). Livestock keeping and access to grazing land had significantly positive effects of the FCS $(P=1 \%$ in both cases). In addition, FCS was significantly higher in households where the head was formally employed $(P=10 \%)$. Households that reported that they had experienced lack of food during the last 12 months year posted significantly lower FCS rendering credence to their claim.

\section{Discussion}

Although farming is the principal source of livelihood among livestock keepers in Botswana, most of them rely on purchased foodstuffs including main staples and livestock products such as milk for home consumption. As most food commodities available in food stores in Botswana are imported, this makes local people potentially vulnerable when world food commodity prices rise as has been the case recently. This calls for close monitoring of the situation by the government in order to ensure that poor households do not suffer when world and subsequently domestic food commodity prices rise. Moreover, even as the government 
opens up to food commodity imports in pursuit of food security, it should not disregard promotion of local production and consumption of agricultural commodities in cases where this is technically and economically feasible.

An appreciable number of households in Botswana suffer food insecurity, and the problem is more prevalent in rural districts (up to $13 \%$ of households) than in urban areas. ${ }^{5}$ The estimated prevalence of food insecure households using the FCS in this study can be regarded as conservative because as past studies have shown the methodology has a tendency to underestimate the prevalence of food insecurity. Despite this drawback, the methodology is generally accepted as reliable and is widely used. Moreover, with $20 \%$ of households, claiming that they had endured going to bed hungry during the preceding 12 months prior to the collection of data used in this study, the FCS estimates of food insecurity prevalence seem credible. This reasoning is also supported by empirical results from this study which show that households which claimed to have suffered lack of food during the past 12 months were significantly more likely to have poor FCS and therefore be food insecure.

Findings from the econometric analysis demonstrate important relationships between food security and a number of factors. Households with livestock keeping as their main activity were less food insecure. This justifies government investments that could make the livestock sector more competitive and attractive for people/households to invest in. For example, much of research and investment in the past has been accorded to the beef subsector, while small ruminants and other livestock species have received relatively less attention. It may be highly beneficial for the government to explore how the rearing and marketing of small ruminants could be enhanced so as to widen the opportunities available in the livestock sector. Note that rearing of different species of animals provides a way of optimising land use besides diversification of sources of income for farmers. Likewise, ways through which sustainable access to grazing land by poor farmers' should be explored as this clearly enhances food security in households. Moreover, better livestock market opportunities might replicate to higher household income, hence food security, although past studies ([28, 29]) have showed the relation between herd size and gross margin in Botswana is not straightforward. In this study, the number of cattle and shoats kept by the households which resulted in non-significant effect on FCS was largely expected to impact the food security status of

\footnotetext{
${ }^{5}$ According to Acquah et al. [6], the food insecurity among poor Gaborone inhabitants is about $62 \%$. However, since the study purposefully targeted poor households, the value cannot represent the rate of food insecurity in urban area.
}

the households. Bahta and Malope [30] found that farmers with large cattle herds are more efficient in terms of profit. However, their study also acknowledged that the relationship between herd size and gross margin in Botswana is a complex one and they further indicated other previous studies ([28]; BIDPA 2006) that have shown that farmers who own more than 200 cattle have the highest gross margin, while farmers with less than 20 TLU in Bahta et al. [28] and with 150-200 TLU cattle herd size in BIDPA (2006) experienced a negative gross margin. Similarly, ownership small stock (shoats), which are widely used as a source of food security in many sub-Saharan Africa, are less marketable in Botswana as there are not any formal or informal small stock markets.

The aforementioned together with the cultural tendency of livestock overstocking as symbols of wealth and prestige could have left rural households food in secure regardless the number of cattle or shoats they possess.

Findings from the current study also give clues on how targeting of safety net interventions to mitigate food insecurity should be done. With food insecurity being more prevalent in the rural areas, more attention should be placed there. Households with a higher number of adult persons are less likely to be food insecure and should therefore attract less attention. Although households with higher number of children were less food insecure, this probably reflects the effects of ongoing efforts that target children in ensuring food security.

\section{Conclusions and recommendations}

This study set out to characterise food consumption patterns and food security situation among livestock keepers in Botswana. The study also sought to determine the effect of various factors (including livestock-related issues) on nutrition/food consumption patterns. The study utilised data from a survey conducted by International Livestock research Institute (ILRI) and its partners on 600 livestock keepers in 2013. Based on WFP's method of measuring food security in communities, we computed a food consumption score (FCS) which was then used to generate a hierarchical ranking of households in terms of their food security status. The results of the FCS were used to ground truth farmers' claims about their food security situation. Regression analysis including both logit and OLS models was utilised to determine the effect of various factors on food security status of farm households.

It was found that purchase is the chief source of foodstuffs (including main staples) among livestock keepers in Botswana. Fish and goat meat were the leading source of animal proteins in households. About $20 \%$ of the surveyed households claimed that they had suffered lack of food at least once in the preceding 12 months prior to 
the household survey with nearly all of them having had to endure going to bed hungry. The FCS confirmed this claim by the survey respondents. On the basis of the FCS, about $9 \%$ of households were found to be food insecure. This included $6 \%$ that ranked poorly and $3 \%$ that were on the borderline according to the WFP's definition of food security. Households that reported that they had experienced lack of food during the 12 months preceding study posted significantly lower FCS rendering credence to their claim.

The results from this study justify continued, but welltargeted efforts to ensure realisation of food security among livestock keepers in Botswana. The significant effect that livestock keeping has on food security implies that promotion of the livestock activities, especially in the rural areas, could foster alleviation of malnutrition, especially among the poor. Perhaps the government and the people of Botswana could save some money by encouraging consumption of locally produced foodstuffs where this is technically and economically feasible.

\section{Authors' contributions}

Conception and design of the work proposal, collection of data, interpretation of data and drafting the manuscript article were performed by SB and FW. Analysis and the initial result interpretation were conducted by FW. Revising the manuscript critically for intellectual content and the final was conducted by SB, HK and DM. All authors read and approved the final manuscript.

\section{Author details}

${ }^{1}$ International Livestock Research Institute (ILRI), Gaborone, Botswana. ${ }^{2}$ International Livestock Research Institute (ILRI), Nairobi, Kenya. ${ }^{3}$ World Bank Group (WBG), Addis Ababa, Ethiopia. ${ }^{4}$ Botswana University of Agriculture and Natural Sciences (BUAN), Gaborone, Botswana.

\section{Acknowledgements}

The assistance and collaboration of local district authorities, and extension agencies in the South East, Central and Chobe districts of Botswana are gratefully acknowledged, as is the co-operation of farm households selected for the survey.

\section{Competing interests}

The authors declare that they have no competing interests.

\section{Availability of data and materials \\ The data sets used and/or analysed during the current study are available from the corresponding author on reasonable request. Raw data will also be placed in the open-access International Livestock Research Institute (ILRI) Data Portal. http://data.llri.org/portal/. The ILRI Data Portal is an archive of ILRI data- sets. The metadata of all ILRI datasets are publicly available. Access to the data may also be publicly available or only downloadable for registered users. Pub- lic available data do not contain sensitive information like names or telephone numbers. Full access to data is given on request. For more information, read our Open Data Policy available here http://data.ilri.org/portal/policy.}

\section{Consent for publication}

Not applicable.

\section{Ethics approval and consent to participate} Not applicable.

\section{Funding}

This study was conducted as part of the Competitive Smallholder Livestock in Botswana project, funded by the Australian Centre for International Agricultural Research (ACIAR) and implemented by the International Livestock
Research Institute and the Botswana Ministry of Agriculture's Department of Agricultural Research.

\section{Publisher's Note}

Springer Nature remains neutral with regard to jurisdictional claims in published maps and institutional affiliations.

Received: 21 July 2017 Accepted: 15 November 2017

Published online: 01 December 2017

\section{References}

1. UNDP. Botswana study guide, strategic information and developments. Washington DC: International Business Publications. 2012; 1.

2. Statistics Botswana. Annual agricultural survey report 2013. Gaborone: Statistics Botswana; 2014.

3. Botswana. The world factbook. Central Intelligence Agency, 2014. http:// www.cia.gov/library/publications/the-world-factbook/geos/bc.html.

4. World Bank. Botswana social protection assessment. Geneva: World Bank; 2013.

5. MFDP. Ministry of finance and development planning, national development plan (NDP) 10. Gaborone: Government Printers; 2010.

6. Acquah B, Kapunda S, Legwegoh A, Gwebu T, Modie-Moroka T, Gobotswang K, Mosha A. The state of food insecurity in Gaborone. In: Crush J (ed) Urban Food Security Series Cape Town: Urban Food Security Network. pp.1-38; 2013.

7. BIDPA. Rising global food prices: causes and implications for Botswana. BIDPA briefing paper 2008.

8. FAO. Biofuels: prospects and opportunities. Rome: FAO; 2008.

9. MFDP. Ministry of finance and development planning, national development plan 11. Gaborone: Government Printers; 2016.

10. ILRI, ACIAR, Botswana MOA. Competitive smallholder livestock in Botswana: report of the second project partners meeting on in Gaborone, Botswana; 2014.

11. Moreki JC, Dikeme R, Poroga B. The role of village poultry in food security and HIV/AIDS mitigation in Chobe District of Botswana. Livest Res Rural Dev. 2010;22.

12. Legwaila GM, Mojeremane W, Madisa ME, Mmolotsi RM, Rampart M. Potential of traditional food plants in rural household food security in Botswana. J Hortic For. 2011;3(6):171-7.

13. WFP and FAO. Measures of food consumption — harmonizing methodologies. Rome: WFP; 2008.

14. Wfp VAM. Food consumption analysis: calculation and use of the food consumption score in food security analysis. Rome: WFP; 2006.

15. Gina K, Berardo A, Papavero C, Horjus P, Ballard T, Dop M, Delbaere J, Brouwer ID. Proxy measures of household food consumption for food security assessment and surveillance: comparison of the household dietary diversity and food consumption scores. Public Health Nutr 2010: 13(12):2010-18.

16. Ben-Akiva M, Bierlaire M. Discrete choice methods and their applications to short-term travel decisions. In: Hall R, editor. Handbook of transportation science. International series in operations research and management science. Dordrecht: Kluwer Academic; 1999. p. 23.

17. Green W. Econometric analysis. 7th ed. Edinburgh Gate: Pearson Education Limited; 2012.

18. Garret J, Ruel M. Are determinants of rural and urban food security and nutritional status different? Some insights for Mozambique. World Dev. 1999;27(11):1955-75.

19. De Muro P, Burchi F. Education for rural people and food security: a cross country analysis. Rome: Food and Agriculture Organization (FAO); 2007.

20. Mrkic S, Johnson T, Rose M. World's Women 2010: Trends and Statistics. New York: United NationsDepartment of Economic and Social Affairs; 2010.

21. Chobe District Council. Chobe District Development Plan 6: 2003-2009. Government Printer, Gaborone;2003.

22. South East District Council. South East District Development Plan 6:20032009. Government Printer,Gaborone; 2003 
23. Moepeng P, Tisdell C. The socio-economic situation of female heads and poor heads of households in rural botswana: a village case study. Social Economics, Policy and Development, the University of Queensland, Brisbane. Working Paper 48; 2008.

24. Statistics Botswana. Household income and expenditure survey 2002/03. Gaborone: Government Printer; 2004.

25. Joshi S. Female household-headship in rural Bangladesh: incidence, determinants and impact on children's schooling. New Haven: Yale University; 2004.

26. Statistics Botswana. Botswana core welfare indicators survey 2009/10. Main report 2013; 1

27. Statistics Botswana. Population and housing census 2011 analytical report. Gaborone: Statistics Botswana; 2011.
28. Bahta S, Baker D, Podisi B, Marobela O. Competitive smallholder livestock in Botswana: results of a livestock value chain survey in the Central district of Botswana. Gaborone, Botswana: International Livestock Research Institute (ILRI); Nairobi, Kenya; 2013.

29. BIDPA. Final Report on the Viability and Long-term Development Strategy for the Livestock (Beef) sub-sector in Botswana. Botswana Institute for Development and Policy Analysis, Gaboron; 2006.

30. Bahta S, Malope P. Measurement of competitiveness in smallholder livestock systems and emerging policy advocacy: an application to Botswana. Food Policy. 2014;49:408-17.

\section{Submit your next manuscript to BioMed Central and we will help you at every step:}

- We accept pre-submission inquiries

- Our selector tool helps you to find the most relevant journal

- We provide round the clock customer support

- Convenient online submission

- Thorough peer review

- Inclusion in PubMed and all major indexing services

- Maximum visibility for your research

Submit your manuscript at www.biomedcentral.com/submit 